\title{
DEPDC5 wt Allele
}

National Cancer Institute

\section{Source}

National Cancer Institute. DEPDC5 wt Allele. NCI Thesaurus. Code C148376.

Human DEPDC5 wild-type allele is located within $22 q 12.2-q 12.3$ and is approximately 153 $\mathrm{kb}$ in length. This allele, which encodes GAT OR complex protein DEPDC5, is involved in the modulation of signaling by Ras-related GT P-binding proteins. Mutations in this gene are associated with autosomal dominant familial focal epilepsy with variable foci and with an increased risk of hepatocellular carcinoma in individuals with chronic hepatitis C virus infection. 